\title{
Melanism in Vipera aspis francisciredi (Laurenti, 1768) (Reptilia Serpentes) in the Lazio Region (Parco Naturale Regionale dei Monti Simbruini), Italy
}

\author{
Nicolò Borgianni' \& Giovanni Paolino² \\ ${ }^{1}$ Vicolo della Cittadella 15A, 00019, Tivoli, Italy; email: fuser88@live.com \\ ${ }^{2}$ Viale Lombardia 64, 20131, Milano; email: gio8519@gmail.com \\ *Corresponding author, email:
}

\begin{abstract}
With this note we report the presence of melanic individuals of Redi's viper Vipera aspis francisciredi (Laurenti, 1768) (Reptilia Serpentes) in the Lazio region (Parco Naturale Regionale dei Monti Simbruini), Italy. Although the presence of melanic and melanistic individuals in the region is known, up to date, there are no official reports of this, in particular with regard to the territory of the Parco Naturale Regionale dei Monti Simbruini. The distribution on the national territory of melanic and melanistic individuals belonging to the subspecies Vipera aspis francisciredi is little known, therefore more in-depth studies on the distribution of the melanic phenotype in Italian populations would be of particular interest.
\end{abstract}

KEY WORDS

Melanism;Parco Naturale Regionale dei Monti Simbruini; Redi's viper; Vipera aspis francisciredi.

Received 17.03.2020; accepted 26.05.2020; published online 30.06.2020

\section{INTRODUCTION}

Melanism is an excess of black pigmentation due to overproduction and/or dispersion of melanin from melanophores (tegumentary cells containing melanins belonging to the chromatophores category) (Sherbrooke et al., 1989) that can be found in many animal species, including snakes. In ectotherms, at similar values of temperature, solar radiation intensity and wind speed, individuals with a dark phenotype (with low reflectivity on the skin) warm up more quickly and consequently are able to maintain optimal body temperatures more easily than lighter coloured individuals (De Jong et al., 1996; Clusella-Trullas et al., 2007). At the same time, darker individuals are less cryptic, and therefore more vulnerable to predation (Clusella-Trullas et al., 2007). Melanic specimens are able to colonize environments with a greater plant cover, and therefore cooler and wetter, thanks to the superior heat absorption capacity due to the dark color; accordingly, the disadvantage due to reduced cryptic capacities is probably compensated by the speed with which the ideal temperature can be reached (Castella et al., 2013).

Vipera aspis francisciredi (Laurenti, 1768) (Reptilia Serpentes) is a subspecies of $V$. aspis (Linnaeus, 1758) present in central and northern Italy, southern Switzerland and Slovenia, with dorsal patterns consisting of small bands, darkcoloured spots or triangles and the accentuated polymorphism of the basic colour covering a wide range of grey, reddish, brown and sand tones. Regarding melanic specimes of this species, there is one area in central Italy where partially or totally black individuals live, but whose presence has never been officially registered in the Italian Lazio Region. 
See also other cited references: Bruno, 1976, 1985; Brodmann, 1987; De Smedt, 2006; Di Nicola et asl., 2019.

\section{MATERIAL AND METHODS}

The specimens reported in Table 1 were sighted during the monitoring of the project "I rettili del Parco Naturale Regionale dei Monti Simbruini" and where, when possible, captured, sexed and released at the place of capture (Figs. 1-4).

A report was also collected together with photographic material from the Park staff and two specimens preserved under alcohol from a private collection and conserved in the "Museo della civiltà contadina" in Filettino (Frosinone, Italy) (Table 1).

Field work was carried out in the Regional Natural Park of the Simbruini Mountains (PNRMS), established in 1983, that with its about 30,000 hectares is the largest protected area in the Lazio Region, characterized by a low level of anthropization and a wide spread of forests: about $70 \%$ of the surface is in fact covered by forest formations of both beech forests and mixed deciduous and coniferous reforestation.

The Park territory is included in 7 municipalities: Camerata Nuova, Cervara di Roma, Subiaco, Jenne and Vallepietra in the province of Rome, Trevi nel Lazio and Filettino in the province of Frosinone. The protected area is included almost entirely in the SPA Monti Simbruini - Monti Ernici IT6050008 and includes 7 Sites of Community Importance (SIC).

\section{DISCUSSIONS AND CONCLUSIONS}

Melanism is frequent in a polymorphic taxa such as the genus Vipera Laurenti, 1768. In particular in Italy, the presence of melanic individuals of Vipera berus (Linnaeus, 1758) and Vipera walser Ghielmi, Menegon, Marsden, Laddaga et Ursenbacher, 2016 along the Alpine arc is known, On the contrary, the presence of melanic or melanistic individuals of Vipera ursinii has never been recorded in the peninsula. Among the Italian species, the one that presents the greatest variability in terms of coloration and dorsal ornamentation is certainly Vipera aspis (Linnaeus, 1758), mainly due to its wide distribution along the peninsula and the rich variety of colonized habitats. Melanism is relatively common among the individuals of Vipera aspis aspis, distributed in alpine habitats, but regarding Vipera aspis hugy, with such coloration, there is only one report (Di Nicola \& Meier, 2013), while for Vipera aspis francisciredi its presence, over the years, has been sporadically reported in the literature, along the distribution range of this subspecies.

Given the altitudinal distribution of the individuals found during the present study (average elevation $1587.75 \mathrm{~m}$ ) and their presence within the vegetation limits, it is possible to assume that melanism in Vipera aspis francisciredi is mainly due to thermoregulatory requirements due to the advantage given by a dark coloration in cool areas with wide tree cover (consequently shady and with low presence of predators such as birds of prey)

\begin{tabular}{|ccccc|}
\hline Sex & Date & SVL & Altitude & Habitat \\
F & 22.V.1985 & $50 \mathrm{~cm}$ & $1400 \mathrm{~m}$ & - \\
M & 30.IX.1985 & $56 \mathrm{~cm}$ & $1604 \mathrm{~m}$ & - \\
- & 07. VII.2015 & - & $1740 \mathrm{~m}$ & bushy pasture \\
- & 01. IX.2016 & - & $1596 \mathrm{~m}$ & forest \\
M & 15.VII.2018 & - & $1727 \mathrm{~m}$ & forest \\
F & 06.IX.2018 & - & $1718 \mathrm{~m}$ & bushy pasture \\
- & 12.VII.2018 & - & $1483 \mathrm{~m}$ & forest \\
F & 10.IX.2019 & $60 \mathrm{~cm}$ & $1434 \mathrm{~m}$ & forest \\
\hline
\end{tabular}

Table 1. Baselines features of the studied specimens of melanic Vipera aspis francisciredi. 


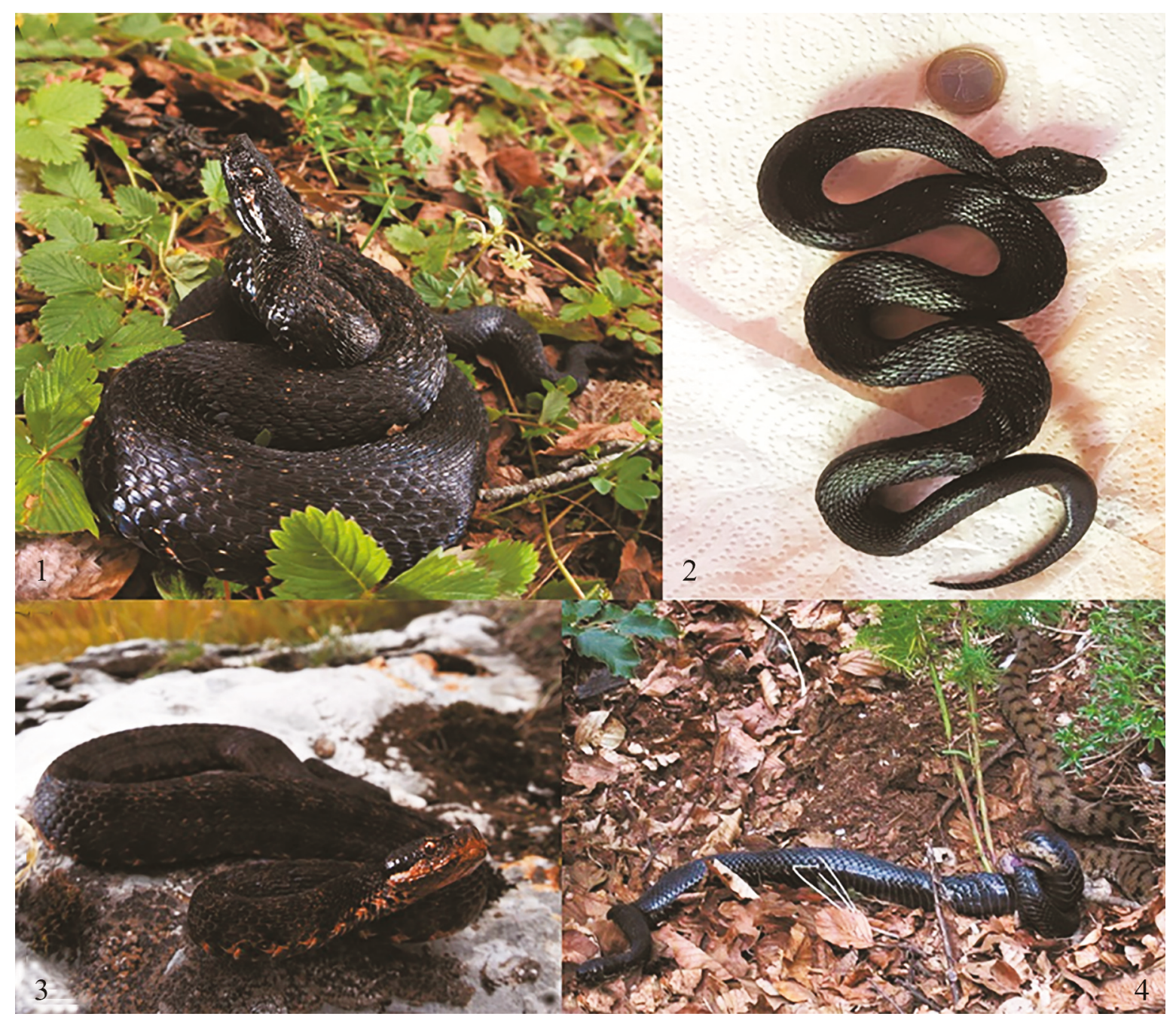

Figure 1. Male specimen observed on the edge of a beech forest (Filettino, Frosinone, Italy). Figure 2. Male specimen preserved under alcohol and belonging to a private collection (Filettino, Frosinone, Italy). Figure 3. Female specimen observed in a bushy pasture (Filettino, Italy). Figure 4. Mating between a melanic individual and one with normal phenotype (Guarcino, Frosinone, Italy).

(Castella et al., 2013). It would therefore be appropriate to deepen the research by including a larger number of individuals and populations, focusing attention on their distribution and fitness of melanic individuals compared to those with cryptic coloration present in the same area.

\section{ACKNOWLEDGEMENTS}

The authors thank the Parco Naturale Regionale dei Monti Simbruini organization (Lazio, Italy) for the collaboration during the work on the project "I ret- tili del Parco Naturale Regionale dei Monti Simbruini”; Francesco Rossi (Filettino, Frosinone, Italy) for the numerous reports and the great availability and Dr, Matteo Di Nicola (Milano, Italy) for the bibliographical help.

\section{REFERENCES}

Brodmann P., 1987. Die giftschlanger Europas und die gattung Vipera in Afrika und Asien. Bern: Kümmerly + Frey. 148 pp.

Bruno S., 1976. L'ornamentazione della Vipera aspis (L., 1758) in Italia (Serpentes Viperidae) (Studi sulla 
fauna erpetolologica italiana. XXI). Atti della Società italiana di scienze naturali e del Museo civico di storia naturale di Milano, 117: 165-194.

Bruno S., 1985. Le vipere d'Italia e d'Europa. Edagricole, 278 pp.

Castella B., Golay J., Monney J.C., Golay P., Mebert K. \& Dubey S., 2013. Melanism, body condition and elevational distribution in the asp viper. Journal of Zoology, 290: 273-280. https://doi.org10.1111/jzo. 12037

De Jong P., Gusseklo S. \& P. Brakefield P., 1996. Differences in thermal balance, body temperature and activity between non-melanic and melanic two-spot ladybird beetles (Adalia bipunctata) under controlled conditions. Journal of Experimental Biology, 199: 2655-2666.
De Smedt J., 2006. The Vipers of Europe. Eigenverlag, Halblech, 340 pp.

Di Nicola M.R., Cavigioli L., Luiselli L. \& Andreone F., 2019. Anfibi \& Rettili d'Italia. Edizioni Belvedere, Latina, le scienze" (31), 568 pp.

Di Nicola M.R. \& Meier G.J., 2013. Vipera aspis hugyi (Southern italian ssp). Melanism. Herpetological Review, United States, 44: 698.

Sherbrooke W.C. \& Frost S.K.V., 1989. Integumental chromatophores of a color-change, thermoregulating lizard, Phrynosoma modestum (Iguanidae, Reptilia). American Museum novitates, no. 2943. http://hdl. handle.net/2246/5101

Trullas S.C., van Wyk J.H. \& Spotila J.R., 2007. Thermal melanism in ectotherms. Journal of Thermal Biology, 32: 235-245. 